\title{
Management Praxis at Nepalese Manufacturing and Non-Manufacturing Firms
}

\author{
Raj Kumar Bhattarai, PhD \\ Associate Professor, Nepal Commerce Campus
}

\begin{abstract}
This paper ascertains management praxis at Nepalese manufacturing and non-manufacturing firms that are shaping the firms' decisions and actions in due course of their managerial process activities. In-depth interviews with selected executives from among the respondents and discourse analysis thereof indicate a varied form of managerial practices. The discourse in the areas of organizational change and management praxis concentrated on the adaptation to their environment. It focuses on the role of executives, culture, environmental change, organizational and business legacy in consideration of discontinuity, innovation and social adaptation. Chisquare test of independence and Kendall's tau-b have been instrumental in interpretation of the associations and relationships of the principal actors of change makers in organizations and businesses.
\end{abstract}

Key words: management praxis, change maker, environmental adaptation, intelligence

Human and their organizations continue to grow and evolve and that take nurturing (Denton, 1998). More success in management is likely to be achieved by changing people's attitude and values rather than changing their working environment and technology (Bland, 1999). The business network, actor relationships, and the patterns of works influence the most in organization and management. Global corporations need the business manager, the country manager, the functional manager, and the corporate manager as well (Bartlett \& Ghoshal, 1992). Corporate citizenship is a priority component in building and strengthening global governance structures (Marsden, 2000). Executives desiring improved performance may well find it worthwhile to investigate and implement novel organizational designs and strategy. There is significance of managerial practices in order to enhance the understanding on organizations and businesses in manufacturing and non-manufacturing sectors.

Change interventions require positive attitude of personnel and the attitude depends on stress-level of the persormance. Work and family demands may cause life stress among the employees. Contrary to the expectations, work demands appear to have a lesser impact on life stress than family demands, although the difference is not substantial (Edgar \& Geare, 2005). Furthermore, while the effect of family demands on life stress is fully mediated by work-family conflict, work demands affect life stress both directly and indirectly through work-family conflict.

Methods

The study paradigm was management praxis in manufacturing non- 


\section{Pravaha Journal-2018}

manufacturing firms being operational in Nepal under a highly dynamic environment of the study period of the first half of the year 2017. The paradigm is assumed in the form of managerial practices in due course of the organizations and business. The methodological aspect of the study consists the theories, executive discourse, management praxis, and opinions of the key informants in manufacturing and nonmanufacturing industries. The research method consists a sequence of literature review in order to understand the concepts and perspectives, executive interviews for the discourse and management praxis, and personal consultations for the opinions of the key informants. The archives, checklist and semi-structured questionnaire were the tools of information collection. The information obtained as such were arranged in the categories of congruence and incongruence with the well-established assumptions in the process of managerial process activities. This paper consists the category of congruence of the assumptions

Chi-square statistics and Kendall's tau-b are major statistical tools of this study. Chi-square test for independence indicates that whether the frequencies associated with two variables (with two or more categories each) are statistically independent of or dependent upon one another. Each cell is in the contingency table represents a joint relationship between one categories from each variable. This test reveals whether the relationship between two (or more) manufacturing and non-manufacturing industries is a dependent one- that is, both the industries need to consider simultaneously- and whether they are actually independent of one another. If the chi-square value equals or exceeds a critical value, then the null hypothesis of independence rejected and the two variables are in a dependent relationship with one another.

The null hypothesis, while making comparison between manufacturing and nonmanufacturing firms is that both the firms are independent. The varying pattern of frequencies shown in the contingency table, then, is due to chance rather than any dependent relationship. Alternatively, manufacturing and non-manufacturing are dependent i.e. the changes interventions are concerning both the industries.

The formula for calculating $\chi^{2}$ value, in case of row and column, the following formula is used.

$$
\chi^{2}=\sum_{r=1} \sum_{c=i} \frac{\left(f_{o}-f_{e}\right)^{2}}{f_{e}}
$$

In the above formula, $\mathrm{r}$ is the number of rows and $\mathrm{c}$ is the number of columns. This formula directs the data analysis to determine the difference between the observed $f_{0}$ and expected $f_{e}$ frequencies in a given cell, square that difference, and then divide it by the expected frequency. The following formula obtains the expected frequency.

Kendall's tau $(\tau)$ is non-parametric correlation coefficient useful to use when there are a large number of tied scores. The coefficient is representing the effect size as well but it is not squared as Pearson's correlation coefficient, r, is squared. Kendall's statistic is actually better estimate of the correlation in such type of data set. It is a more accurate gauge of what the correlation in the population would be (Field, 2009).

In case of $2 \times 2$ contingency table, for two variables A (say) industry type and variable B (say) organization structure, a pair of observation is concordant if the subject that ranks higher on variable A also ranks higher on variable B. Similarly, a pair is said to be discordant if the subject that ranks higher on A ranks lower on $\mathrm{B}$. The 
following formula obtains the Kendall's tau coefficient (Lawal, 2003).

$$
\begin{aligned}
\tau & =\frac{2(C-D)}{\sqrt{\left(C+D+T_{A}\right)\left(C+D+T_{B}\right)}} \\
C & =n_{i j}\left(\sum_{u=i+1}^{I} \sum_{v=j+1}^{J} n_{u v}\right) ; D=n_{i j}\left(\sum_{u=i+1}^{I} \sum_{v=1}^{J-1} n_{u v}\right) \\
T_{A} & =\frac{1}{2} \sum_{i} n_{i+}\left(n_{i+}-1\right) ; T_{B}=\frac{1}{2} \sum_{j} n_{+j}\left(n_{+j}-1\right)
\end{aligned}
$$

The Kendall's tau-b coefficient is more effective in determining whether two nonparametric data samples with ties correlate or not. The values of tau-b range from -1 (100\% negative association, or perfect inversion) to +1 (100\% positive association, or perfect agreement). A value of zero indicates the absence of association. SPSS provides the significant of the relationships between the variables. The tau-b coefficient less than \pm 0.09 indicate insignificant or weak relationship and the coefficient \pm 0.10 and above indicate significant or strong relationship.

\section{Analysis}

Respondents' demography indicates that there were very few female employees in the surveyed organizations. Female proportion of the respondent is only about 20 percent when compared with their male counterpart. The data generated by this study indicates that both the manufacturing and non-manufacturing industries are male dominated in all the ways.

Academic qualification of the respondents and their job matching were quite interesting. More than $90 \%$ of the respondents were master and bachelor degree holders. Composition of the respondents indicates that there is compulsion of being attached to any job in any type in the industry for the respondents. Academic qualification of respondents ranging from doctoral level to the below SLC could not commensurate their position in their organizations.

The study attempts to include well-educated and highly experienced respondents in order to accumulate reliable responses. People with longer period of association and experience would have better judgments and they are witness of the changes taking place in their organizations. The average experience of the respondent was more than 12 years and average age of them was about four decades. Table 1 provides additional information about the number of respondents and their organizations.

Table 1: Description of organizations

\begin{tabular}{clc}
\hline SN & \multicolumn{1}{c}{ Particulars } & Quantity \\
\hline 1 & Number of manufacturing respondents & 174 \\
2 & Number of non-manufacturing respondents & 241 \\
3 & Total number of respondents & 415 \\
4 & Total number of employees in the organizations (Mean \pm SD) & $140.61 \pm 371.71$ \\
5 & Annual turnover (Mean \pm SD) in million Rs. & $467 \pm 7983.15$ \\
\hline
\end{tabular}




\section{Change makers and adapters}

There are changes in the organization and business. The organization's top-level management and administration, consultants and experts, employees and their unions as well as the organizational culture of learning are facilitating the changes. Inquiry $\mathrm{D}$ was carrying out to determine the instrumentality of the makers of the changes in the organizations. It is necessary to determine that whose role remains significant while facilitating changes in the organizations and business. The role of the top-level management and administration was more instrumental in facilitating changes among others. The Chi-square test statistics carried out to determine the association between industry type and the instrumentality of the role of change facilitators at one part and it obtained Kendall's tau-b correlation coefficients to determine the relationships between the makers of the changes on the other part.

The role of change makers reflected in inquiry indicates that top-level management and administration was more instrumental in facilitating the changes in the organization and business. Chi-square statistics $X^{2}(1, N=415)=0.037, p=.847$ $>.05$ indicated that the industry type of manufacturing and non-manufacturing firms (Table ) has no statistical association with the instrumentality of top-level management in facilitating the changes in different areas in the organizations and businesses. The chi-square value of 0.037 is less than the critical value 3.84 , which is leading to the acceptance of the null hypothesis that the industry type of manufacturing and nonmanufacturing firms and the role of top-level management in making change were independent. However, the p value of .847 is greater than confidence level .05, which indicates that a simultaneous consideration is necessary in both the industries because of an insignificant statistical association of the industry type and role of the top-level management and administration in making changes.

Table 2: Role of top management in making change in organization

\begin{tabular}{llccc}
\hline \multirow{2}{*}{ Industry } & & \multicolumn{2}{c}{ Top management/administration } & \\
\cline { 3 - 4 } & & $\begin{array}{c}\text { Passive in bringing } \\
\text { change }\end{array}$ & $\begin{array}{c}\text { Active in bringing } \\
\text { change }\end{array}$ & Total \\
\hline \multirow{2}{*}{ Manufacturing } & Count & 102 & 72 & 174 \\
& \% within Industry & 58.6 & 41.4 & 100 \\
\multirow{2}{*}{ Non-manufacturing } & Count & 139 & 102 & 241 \\
& \% within Industry & 57.7 & 42.3 & 100 \\
\hline \multirow{2}{*}{ Total } & Count & 241 & 174 & 415 \\
& \% within Industry & 58.1 & 41.9 & 100 \\
\hline
\end{tabular}

The instrumentality of change facilitators reflected in the inquiry (Table 3) indicated that the consultant and expert advices are also instrumental among others in facilitating changes in the organization and business. The chi-square statistics $\mathrm{X}^{2}$ $(1, \mathrm{~N}=415)=2.963, \mathrm{p}=.085>.05$ indicated that the industry type of manufacturing and non-manufacturing firms (Table) have no statistical association with the role of consultant or expert advices in facilitating the changes in the organizations and businesses. The chi-square value of 2.963 is less than the critical value 3.84 , which is leading to the acceptance of the null hypothesis that the industry type of manufacturing and non-manufacturing firms and role of consultant or expert advices 
were independent. However, the $\mathrm{p}$ value of .085 is greater than confidence level .05, which indicates that a simultaneous consideration is necessary in both the industries because of an insignificant statistical association of the industry type and the role of the consultant and expert advices.

Table 3: Role of consultants and experts in making change

\begin{tabular}{llccc}
\hline \multirow{2}{*}{ Industry } & \multicolumn{2}{c}{ Consultants/experts } \\
\cline { 3 - 4 } & & $\begin{array}{c}\text { Passive in bringing } \\
\text { change }\end{array}$ & $\begin{array}{c}\text { Active in bringing } \\
\text { change }\end{array}$ & Total \\
\hline \multirow{2}{*}{ Manufacturing } & Count & 140 & 34 & 174 \\
& \% within Industry & 80.5 & 19.5 & 100 \\
\multirow{2}{*}{ Non-manufacturing } & Count & 209 & 32 & 241 \\
& \% within Industry & 86.7 & 13.3 & 100 \\
\hline \multirow{2}{*}{ Total } & Count & 349 & 66 & 415 \\
& \% within Industry & 84.1 & 15.9 & 100 \\
\hline
\end{tabular}

The role of change facilitators reflected in the inquiry indicated that employees or unions were more active in facilitating changes in the organization and business. Chisquare statistics $\mathrm{X}^{2}(1, \mathrm{~N}=415)=0.442, \mathrm{p}=.506>.05$ indicated that the industry type of manufacturing and non-manufacturing firms (Table) have no statistical association with the role of employees and their unions in facilitating the changes in organizations and businesses. The chi-square value of 0.442 is less than the critical value 3.84, which is leading to the acceptance of the null hypothesis that the industry type of manufacturing and non-manufacturing firms and role of employees and their unions were independent. However, the $\mathrm{p}$ value of .506 is greater than confidence level .05, which indicates that a simultaneous consideration is necessary in both the industries because of an insignificant statistical association of the industry type and the role of the employees and their unions in organizations and business.

Table 4: Role of employees and unions in making change

\begin{tabular}{llccc}
\hline & \multirow{2}{*}{ Industry } & \multicolumn{2}{c}{ Employees/unions } & \multirow{2}{*}{ Total } \\
\cline { 3 - 4 } & & $\begin{array}{c}\text { Passive in bringing } \\
\text { change }\end{array}$ & $\begin{array}{c}\text { Active in bringing } \\
\text { change }\end{array}$ & \\
\hline \multirow{2}{*}{ Manufacturing } & Count & 152 & 22 & 174 \\
& \% within Industry & 87.4 & 12.6 & 100 \\
\multirow{2}{*}{ Non-manufacturing } & Count & 205 & 36 & 241 \\
& \% within Industry & 85.1 & 14.9 & 100 \\
\hline \multirow{2}{*}{ Total } & Count & 357 & 58 & 415 \\
& \% within Industry & 86.0 & 14.0 & 100 \\
\hline
\end{tabular}

The role of change makers reflected in the inquiry indicated that organization culture of learning was also active in facilitating changes in the organization and business. Chi-square statistics $\mathrm{X}^{2}(1, \mathrm{~N}=415)=2.083, \mathrm{p}=.149>.05$ indicated that the industry type of manufacturing and non-manufacturing firms (Table 5) have no statistical association with the role of organization culture in facilitating the changes in different areas of organizations and business. The chi-square value of 2.083 is less 
than the critical value 3.84 , which is leading to the acceptance of the null hypothesis that the industry type of manufacturing and non-manufacturing firms and role of the organization culture were independent. However, the p value of .149 is greater than confidence level .05, which indicates that a simultaneous consideration is necessary in both the industries because of an insignificant statistical association of the industry type and the role of the organization culture of learning while making changes in the organizations and businesses.

Table 5: Role of organizational culture in making change

\begin{tabular}{llccc}
\hline \multirow{2}{*}{ Industry } & \multicolumn{2}{c}{ Organization culture } \\
\cline { 3 - 4 } & & $\begin{array}{c}\text { Passive in bringing } \\
\text { change }\end{array}$ & $\begin{array}{c}\text { Active in bringing } \\
\text { change }\end{array}$ & Total \\
\hline \multirow{2}{*}{ Manufacturing } & Count & 157 & 17 & 174 \\
& \% within Industry & 90.2 & 9.8 & 100 \\
\multirow{2}{*}{ Non-manufacturing } & Count & 206 & 35 & 241 \\
& \% within Industry & 85.5 & 14.5 & 100 \\
\hline \multirow{2}{*}{ Total } & Count & 363 & 52 & 415 \\
& \% within Industry & 87.5 & 12.5 & 100 \\
\hline
\end{tabular}

The inquiry on the makers of changes indicates that the top management is the principal actors for making change in both the industry.

The chi-square test statistics reflected the associations between industry type and the roles of change makers in organization and business. It is necessary to determine the nature of relationships between the change facilitators too. Relationships are necessary to determine the nature of their effects while making changes in organizations and businesses. Similar to the other inquiries, the categorical data set in this inquiry also consisted a large number of ties; and Kendall's tau-b considered a reliable statistical tool for determining the relationships between the change makers. The relationships were varying as in Table

Table 6: Relationship between the change makers in organizations

\begin{tabular}{|c|c|c|c|c|c|}
\hline \multicolumn{6}{|c|}{ Kendall's tau_b correlation coefficient } \\
\hline & & D1 & D2 & D3 & D4 \\
\hline \multirow{2}{*}{ Top management/administration } & Correlation Coefficient & 1.000 & & & \\
\hline & Sig. (2-tailed) & . & & & \\
\hline \multirow{2}{*}{ Consultants/experts } & Correlation Coefficient & .044 & 1.000 & & \\
\hline & Sig. (2-tailed) & .366 & . & & \\
\hline \multirow{2}{*}{ Employees/unions } & Correlation Coefficient & -.075 & -.004 & 1.000 & \\
\hline & Sig. (2-tailed) & .128 & .931 & . & \\
\hline \multirow{2}{*}{ Organization culture } & Correlation Coefficient & -.071 & -.045 & -.027 & 1.000 \\
\hline & Sig. (2-tailed) & .149 & .358 & .588 & . \\
\hline
\end{tabular}

There was an adverse relationship between the role of top-level management and administration with the organization culture, employees and their unions while making change in the organizations and business. Top-level management was quite 
close with the consultants or experts and they were seeking advices from them as well.

As discussed earlier, the lower level people are not ready to make decisions at their own even if they are getting authority to do the same from the top. The attitude of working for personal benefits and well-being was one of the most significant barriers in making change in organizations. Both the upper-level executives and the lower-levels were viewing the change interventions from the lens of personal benefits and career advancement.

A serious concern for change managers is that the organization culture and employees and their unions are at one part and the top management and the advices of the experts and consultants are on the other part. It is necessary that all the parties concerned to the change initiatives should come together in order to bring change in real sense. The adverse relationship between top-management and employees / unions was affecting change initiatives in the organization. The assumption of pluralistic interest in organizational setting was another factor leading to the adverse roles relationships. The barriers of organizational culture and union activities were adversely affecting the change interventions in the organizations.

\section{Discussion}

A large number of firms are establishing, operationalizing, and disappearing around us since a very long of managerial history. None of the firms are establishing in view of disappearing after sometimes of its establishment. There is no doubt that environment is dynamic and the assumptions and forecasts made at the time of a firm's establishment change over time. The change may be compatible with the assumptions and forecasts or it may be incompatible or against of the same. A congruence is essential between a firm's commitments and its environmental commandments. Managerial praxis is an attempt of bridging the commandments and commitments.

\section{Corporate culture}

Organizational culture, identity and image are all symbolic, value-based constructions that are becoming increasingly intertwined (Hatch \& Schultz, 1997). There are nine common values pointed out as trust, mutual respect, teamwork, empowerment, risk taking, sense of urgency, and continuous improvement, commitment, and customer satisfaction in organizational setting (Despain, Leinicke, Ostrosky, $\&$ Rexroad, 2003). People intend to find at least one or more role models especially from among those at higher hierarchical levels. Role models are salient to individuals throughout their careers. Metaphors seem to be a strong means of catching especially negative perceptions in organizations. The collective perceptions of employees were stronger in old and well-institutionalized organization. Qualitative analysis tends to reveal the perception of greater productivity, higher morale, increased flexibility and longer work hours due to telework, as well as an equivocal influence on work/life balance and a negative influence on teamwork (Hill, Miller, Colihan, \& Wiener, 1998).

The relationship between culture and behavior might be more completed than research to date suggests- we cannot blindly support that national culture strongly affects behavior in organizations. It is argued that collectivists, more than individualists, have concept derived from in-group identity and relationships with others, are inextricably linking to particular situations or contexts. Classical 


\section{Pravaha Journal-2018}

management principles can potentially provide useful broad guidelines for managers engaged in international planning. The managerial behavior might be influenced by national culture characteristics (Chong \& Park, 2003), therefore, the employers need to look inside each of their working practices, and need to seek an improved design that builds and safeguards for the work-life balance.

\section{Organizational learning}

Organizational learning processes reflect a fundamental shift in management thinking and practice from traditional concept of command and control to more contemporary concepts of facilitation and empowerment. The impact of learning move up from individuals to groups and then to the entire organization. Perceived individual-level learning effectiveness impacts perceived organization-level learning effectiveness. The importance of individual-level learning is not only for individuals and their groups, but also for their entire organization. Cooperative learning, when used in conjunction with work outcomes, has proven itself useful as a meaningful theoretical construct to describe and measure the often difficult-to-measure knowledge creation and dissemination (Janz \& Prasarnphanich, 2003).

Organizational learning refers the adaptation to the changes in operational culture, development of new ways of doing things, norms and paradigms(Lahteenmaki, Toivonen, \& Mattila, 2001). There is mediating role of organizational learning and change resistance in the change process as well. The creativity and innovation processes and the learning processes complement one another, sometimes to a remarkable degree. The potential synergy between the two sets of processes should not be ignored when investments in either are considered.

There is a concept of 'seven dimensions of learning- continuous learning, dialogue and inquiry, team learning, empowerment, embedded system, system connection, and strategic leadership(Zhang, Zhang, \& Yang, 2004). The organizational process is characterized by measurement, detection and correction of errors, and cost reduction. Organizational learning is a single-loop type of an incremental change process, which reminds a technical variant of the learning organization. Continuous improvement occurs through procedural practices which forms a structure for sustaining learning. Organizations emphasizing on organizational learning can realize huge bottom-line benefits. Those do ignore the significance of learning suffer tremendous costs in terms of lost revenues, customers, and markets too.

There is a significant recognition and use of on-the-job or informal learning within an organization. Training, education, supervision, team, mentoring, observation, learning fora, self-helf, projects, shadowing, trial and error, and rotation are the sources of learning. There are evidences that organizations are short-term focused and see little worth in developing management competencies that will produce above average returns in the long run. Surprisingly, there is no support for the notion that competencies have an impact on long-term performance. In some industries, for example, the construction industry at least, the links between short-term priorities and long-term goals are fundamentally at a greater deal.

Adult learning, system theory and psychology were identified as the disciplinary bases of human resource development. Adjusting to changes in work patterns and how work is organized have been considered as a key trend influencing the field(Goh, 2003). 
Issues of professionalization and balancing the needs of employees, organizations and society are identified as key challenges facing the field.

\section{Leadership style}

The dynamic relationship between task and people orientation of leaders may have important performance implications at work places(Adeyemi-Bello, 2001). Psychological empowerment mediates between transformational leadership and the attitudes of followers with respect to general job satisfaction and affective commitment to the organizations. Mentoring can be passive, whereas sponsorship is active. It puts the onus on leaders (McAlearney, 2005). Attaining organizational diversity is a journey; it starts with a commitment of building a culture that supports the mission, and it includes goals to which leaders are held accountable- as well as programs and processes that make the attainment of diversity much more likely.

Transformational leadership is the most effective type for managing change(Yun, Cox, \& Sims, 2007). The propensity of people to undergo role modification will possibly be related to certain underlying cultural or geographical characteristics. The dynamics of team role means that team members autonomously supplant the roles of the missing members. High level of interactions between heads of department, managers and staff help everyone to take responsibility for the quality of their work.

The relationship between dispersed leadership and 'stimulant' dimensions of the work environment for creativity is positive and significant while managing change. The relationship between dispersed leadership, with the exception of encouraging selfreinforcement, and the 'obstacle' dimensions of the work environment for creativity is negative(Politis, 2005). The 'stimulant' dimensions of the work environment for creativity have a positive and significant impact on both creativity and productivity for change. Younger and older managers have different profiles from their consultative and participative leadership styles. Older managers are consulted more widely in comparison with younger mangers.

\section{Quality management}

Total quality management (TQM) has been suggested as a means of coping with turbulent change. It has been expanded to include all areas of management and almost any management approach that works in practice can be considered as quality management. The strong and simple central focus allow an internal war to be waged on complacency that prepares an organization for strong external competition(Michael, Sower, \& Motwani, 1997). This has kept the discipline alive but diluted its significance. The true nature of the discipline can only be understood by revealing its deeper implicit assumptions and by focusing research on those assumptions. TQM managers need to understand existing organizational culture and whether it is compatible with quality culture.

An implementation of technical methods and principles requires a quality in management- managerial values, attitudes, skills, and behavior- that flourish over time(Beer, 2003). Corporate leaders will have to consider requiring all sub-unit managers to lead a regular process of organizational learning from which they also can learn. To create environment of continuous improvement, front-line workers require to see the practical benefits of a structured and planned performance enhancement 
culture and have the appropriate resources to achieve that goal.

Benchmarking requires some conceptual rethinking. It is argued that the need for re-conceptualizing is due to the appearance of three new forms of benchmarking (i.e. a competence benchmarking, a global benchmarking and a networking benchmark) and new fields of benchmarking (i.e. public and semi-public sectors as well as small firms). The earlier stages of benchmarking development efforts and practices stressed an activity and/or process orientation(Fernandez, McCarthy, \& Rakotobe-Joel, 2001). Recently, the applied art of benchmarking has become broader in nature to include strategies and systems. The attention to benchmarking successful customer orientated strategies is especially noted.

\section{International management}

International management practice envournters changes in different categoriesglobal business environment, internationalization, entry mode decisions, international joint ventures, foreign direct investment, international exchange, transfer of knowledge, strategic alliances and networks, multinational enterprises, subsidiaryheadquarters relations, subsidiary and multinational team management, and expatriate management(Werner, 2002).

The expanding international public role of the private sector has both potential benefits and potential dangers. Transnational corporations are increasingly asked to be good corporate citizens and they will continue to enter or be drawn into public roles as providers of private foreign aid, as self-regulators, and as influential political forces in shaping national and international policies. They are sources of enormous wealth and power, some of which can be put to effective use in preventing and alleviating social ills.

In order to succeed in alliance related work, it is necessary to ensure that there are clear strategy and objectives, high trust levels, involvement of the right people, commitment and assurance, and planning for open and frequent communication at the onset of the changes in favor of sustained and aggressive incremental change(Boje \& Rosile, 2003). But, in today's volatile business environment, executives are called on to change their operating models much more frequently than ever before. More often than not, they do not have all the skills and capabilities they need to succeed at the new game. Companies that have fallen behind should consider using business transformation outsourcing to regain their lead.

Firms with an average economic performance were just as likely to adopt environmental initiatives as their high-performing competitors(Hitchens, Thankappan, Trainor, Clausen, \& Marchi, 2005). Moreover, regardless of managers voicing personal concerns about the environment, most small firms do relatively little about the environment in practice and are reluctant to seek advice about it. Managers that define the process as a one-dimensional strategy will be doomed to failure. Effective implementation requires a tailored solution, 'one size does not fit' all firms. Outsourcing must be a part of an overall corporate strategy and management must ensure that all employees are aware of the overall situation. Some combinations of insourcing, outsourcing, and contracting out may be the optimal solution for any particular scenario. 


\section{Environmental adaptation}

Outsourcing invites significant changes in organizations and businesses. It has been a fashionable management technique(Beaumont \& Sohal, 2004). Unlike other management fads, such as quality control or participation, there are good theoretical reasons such as success to economies of scale and expertise for its use. Its practical benefits can be inferred from its growing use. Effective implementation requires a tailored solution, 'one size does not fit' all firms. Outsourcing must be part of an overall corporate strategy and management must ensure that all employees are aware of the overall situation. Some combinations of insourcing, outsourcing, and contracting out may be the optimal solution for any particular scenario.

Given an option, most executives will avoid the disruption of seismic changes in their organizations in favor of sustained and aggressive incremental change(Linder, Cole, \& Jacobson, 2002). But, in today's volatile business environment, executives are called on to change their operating models much more frequently than ever before. More often than not, they do not have all the skills and capabilities they need to succeed in the new game. Companies that have fallen behind should consider using business transformation outsourcing to regain their lead.

Empowerment appears to be a largely subjective and somewhat intangible concept. The three main reasons to this 1) empowerment may be related to positional power; 2) empowerment relates to members' expectations of the gains from the changes and the degree to which these expectation are met; and 3) empowerment also appears to be context-related(Smith \& Mouly, 1998). Empowerment for production workers comes hand-in-hand with closer, long-term efficiency based logic. There exists no single organizational structure or optimal industrial model that best accomplishes this goal, but each level of the organization must contribute value to the overall success of the organization.

\section{Human and natural intelligence}

Changes in human and natural intelligence should be essential looking at the the results that enrich the organization's value to customers, investors, and employees(Ulrich, 1998). Change has a way of scaring people- scaring them into inaction. Role of the personel as a change agent is to replace resistance with resolve, planning with results, and fear of change with excitement about its possibilities. Organizations will need to be in a never-ending state of transformation, perpetually creating fundamental, enduring change. Hence, human resource capability is found to be a significant predictor of sustainable competitive advantage.

The issues of bribery and corruption, training and development, tribalism, and resistance to change are some of the challenges in the process of change management. At the same time, the role of natural intelligence is increasingly assigned to line managers, and that the extent of such assignment varies from organization to organizations(Okpara \& Wynn, 2008). The universal applicability of Anglo-Saxon model of managing natural intelligence is questioned, and a basis for a contextual framework/model for its evaluation in different contexts has been emerging. The model of 'culture fit' suggests that organizational culture is shaped by multiple forces external and internal to the organization.

A wide recognition of the desirability and benefits of commitment are seen in 


\section{Pravaha Journal-2018}

practice along with a clear disparity between the way academics and practitioners conceptualize and measure the employee commitment. Despite the variety of formal measuring tools available, organizational monitoring of commitment can be described as ad hoc and subjective(Shepherd \& Mathews, 2000).

\section{Strategic management}

Strategic management requires a holistic approach with not only an internal integration between organizational systems but also an integration between those systems and the organization's overall strategy. Increasing the core competencies of the firm leads to a high rate of successful firm performance in manufacturing and nonmanufacturing industries.

Every strategy is associated with change in organization and businesses. The great divide in strategy is between the 'design school' and the 'process school' of strategy thoughts. Design school assumes that strategy is usually deliberate and built upon an assumption of economic rationality whereas the process school covers a variety of approaches that how strategies are made and what influence strategy formulation- what actually happens with explanations coming from experience rather than deductive theory(Purcell, 2001).

Strategic management is largely about integration and adaption among business philosophy, policies, programs, practices, processes, culture, tasks, and tradition that involve political compromises as well as serious cognitive challenges(Schuler, 1992). At the same time, there is mixture of both hard and soft approaches of working with people. Factors such as the external and internal environment of the organization, its strategy, culture and structure all have a vital role to play in the way in which strategy operates.

There is an assumption of considering personnel a center point in strategic management (Gunnigle \& Moore, 1994). There are attempts to explore the linkages of business strategy and personnel policy in anticipation of a result of increased competitive pressures, organizations will emphasize the search for competitive advantage and strive to align better personnel policy choice with business strategy.

\section{Performance management}

Employees may agree to be co-operative and participate in new process improvement and change programs subject to their performance and benefits. They may, at some stages, become involved in these activities, thus giving more of themselves in terms of intellectual and affective contribution. There had been considerable policy debate in the European Union concerning job quality and the need to create not only more but also better jobs. There are arguments that organization need not sacrifice profitability in order to provide quality jobs for their employees (Cooke, 2001). However, a mutually beneficial situation is not only feasible but also highly desirable.

There are studies that reveal a range of reasons- from monotonous work, stressful work environment, adverse working conditions, lack of career development opportunities, to better job opportunities elsewhere, which emerge as the key causes of increasing attrition rates in the organization.

Eventually, those items are leading the employees to the acceptance or resistance to the change interventions. The role of unionism is considerable in the process of 
change. There is a shift towards de facto enterprise unionism in the private sector of different industries. However, the degree of this varies and the pace of change has been uneven. There is, therefore, no simple convergence (Becker \& Gerhart, 1996). These changes are in part to be explained by the activities of governments and the actions of unions and their members. More important, however, have been changes in the nature of markets and firms and resultant shifts in bargaining power and employer strategy.

\section{Organizational polity and industrial relations}

From the innovation side, personnel management should be viewed as a strategic and integrated field contributing to the organization as a whole, and not just as fragmented practices supporting specific innovation activities, types or even phases. From the personnel perspective, innovation must not be seen, in a rather static way, as only a one-time strategic choice for the organization as a whole, but related to all kinds of dynamics inside and outside the organization(Bacon \& Storey, 2000). Experts project that within a few years, more than 1.3 billion people will work virtually. A communitybased, low-cost, convenient, and eco-friendly solution like things are changing the organization design quite significantly. "Presenteeism" has come to mean showing up at an office even when the task could be more productive doing from elsewhere.

There are three important sets of factors in shapping the industrial relations- 1) the strategic and organizational factors; 2) the transactional factors; and 3) perceived, risks associated with human resources, with providers and with the results of outsourcing. The innovative recruitment and compensation practices have a positive significant relationship with firm performance. It was observed that recruitment, the role of the HR department and compensation practices seem to be significantly changing these days(Benson \& Gospel, 2008).

\section{Corporate governance}

Good governance needs to abide by certain principles- knowing what governance is; achievement of strategic ends; Board-CEO relationship; unity of direction; unity of command; unity of accountability and responsibility; ownership needs; selfimprovement; and understanding the cost of governance (Taylor D. W., 2000). Prescriptive legislation on corporate governance is likely to be ineffective in preventing corporate misconducts. The monitoring role of independent board members has been recognized. Trust is a key to good corporate governance (Morrison, 2004).

Organizational practice and procedure as well as employee enthusiasm influence the effectiveness of corporate governance and social responsibility (Collier \& Esteban, 2007). Awareness of social responsibility and attitudes of individuals are related in an organizational setting. Individuals have positive attitude towards those companies that are meeting the social responsibility (Sen, Bhattacharya, \& Korschun, 2006). The thematic categories of corporate social responsibility have been identified as high ethical standards, dedication to community service, embracing diversity, employer of choice, compassion for the disadvantaged, commitment to charitable giving, and concern for the environment. The major choices reflected in the strategies of the company include- environmental protection, enlightened employee policies, strategic consistency in replicating the business model in developing countries, and stakeholder awareness raising. 


\section{Conclusion}

The subjective approach adopted by practitioners could inform the approaches of academics just as the structured 'objective' approaches of academics should inform practitioners. Continuation of such practices helps in linking the fundamental changes occuring in academia and businesses.

The change agents are mainly interested in the performance of their department or work unit, and work-life policies are often seen as disruptive. However, when the least disruptive request is considered (short-term leave), the researchers find that dependency arguments also play an important role and managers are more likely to respond to their employees' personal and family needs.

The increasing ease and decreasing cost of innovation mean that as soon as a young organization gets a whiff of success, it has to race against dozens of copycats. Entrepreneurs will continue to give birth to great businesses, and nonprofits will continue striving to build a better society. But the people changing the world today are as likely to be in corporate cubicles and conference rooms or at social-impact conferences. Organizational culture characterized by high adaptability found to have a significant and direct effect on the sustainability of an organizations change practices.

Learning process is embedded in the workplace and shaped by organizational decisions and practices. The hierarchical structuring of relationships make crucial knowledge and information readily availabile to the senior staff, while restricting the availability to the clerks and junior employees. Similarly, organizational decisions make about the design of jobs, and the movement of employees through them, and provided senior managers with knowledge in breadth and depth about the organization and its production/operation system. Eventually, the praxis adopted in an organizational setting, one after another, is attempting to make the firm's commitments and its environmental commandments.

\section{References}

Adeyemi-Bello, T. (2001). The impact of leadership style on organizational growth. Work Study, 50(4), 150-153.

Bacon, N., \& Storey, J. (2000). New employee relations strategies in Britain: towards individualism or partnership? British Joural of Industrial Relations, 38(3), 407-427.

Bartlett, C. A., \& Ghoshal, S. (1992). What is a manager? Harvard Business Review, 70(5), 124-132.

Beaumont, N., \& Sohal, A. (2004). Outsourceing in Australia. International Journal of Operation \& Production Management, 24(7), 688-700.

Becker, B., \& Gerhart, B. (1996). The impact of human resource manangemnt on organizational performance: progress and prospects. Academy of Management Journal, 39(4), 779-801.

Beer, M. (2003). Why total quality management programs do not persist: the role of management quality and implications for leading a TQM transformation. Decision Sciences, 34(4), 623-642.

Benson, J., \& Gospel, H. (2008). The emergent enterprise union? A conceptual and comparative analysis. The International Jouranl of Human Resource Management, 19(7), 1365-1382.

Bland, M. (1999). A new approach to management of stress. Industrial and Commercial Training, 31(2), 44-88.

Boje, D., \& Rosile, G. A. (2003). Comparison of socio-economic and other transorganizational development methods. Journal of Organizational Change Management, 16(1), 10-20.

Chong, J. K., \& Park, J. (2003). National culture and classical principles of planning. Cross Cultural 
Management: An International Journal, 10(1), 29-39.

Collier, J., \& Esteban, R. (2007). Corporate social responsibility and employee commitment. Business Ethics: A European Review, 16(1), 19-33.

Cooke, F. L. (2001). Human resource strategy to improve organizational performance: a route for firms in Britain. International Journal of Management Reviews, 3(4), 321-339.

Denton, D. K. (1998). Creating a winning organization. Empowerment in Organizations, 6(3), 81-93.

Despain, J. E., Leinicke, L. M., Ostrosky, J. A., \& Rexroad, W. M. (2003). Work values at Catterpillar: a process. Organizational Dynamics, 32(4), 405-414.

Edgar, F., \& Geare, A. (2005). HRM practice and employee attitudes: different measures-different results. Personnel Reviews, 34(5), 534-549.

Fernandez, P., McCarthy, I., \& Rakotobe-Joel, T. (2001). An evolutionary approach to benchmarking. Benchmarking: An International Journal, 8(4), 281-305.

Goh, S. C. (2003). Improving organizational learning capability: lessons from two case studies. The Learning Organization, 10(4), 216-227.

Gunnigle, P., \& Moore, S. (1994). Linking business strategy and human resource management: issues and implications. Personnel Review, 23(1), 63-84.

Hatch, M. J., \& Schultz, M. (1997). Relations between organizational culture, identity and image. European Journal of Marketing, 31(5/6), 356-365.

Hill, J. E., Miller, B. C., Colihan, J., \& Wiener, S. P. (1998). Influences of the virtual office on aspects of work and work/life balance. Personnel Psychology, 51(3), 667-683.

Hitchens, D., Thankappan, S., Trainor, M., Clausen, J., \& Marchi, B. (2005). Environmental performance, competitiveness and management of small business in Europe. Royal Dutch Geographical Society, 96(5), 541-557.

Janz, B. D., \& Prasarnphanich, P. (2003). Understanding the antecedents of effective knowledge management: the importance of a knowledge-centered culture. Decision Science, 34(2), 351384.

Lahteenmaki, S., Toivonen, J., \& Mattila, M. (2001). Critical aspects of organizational learning aresearch and proposals for its measurement. British Journal of Management, 12, 113-129.

Linder, J. C., Cole, M. I., \& Jacobson, A. L. (2002). Business transformation through outsourcing. Emerald, 30(4), 23-28.

Marsden, C. (2000). The new corporate citizenship of big business: part of the solution to sustainability. Business and Society Review, 105(1), 9-25.

McAlearney, A. S. (2005). Exploring mentoring and leadership development in health care organizations: experiences and opportunities. Career Development International, 10(6-7), 493-511.

Michael, R. K., Sower, V. E., \& Motwani, J. (1997). A comprehensive model for implementing total quality management in higher education. Benchmarking for Quality Management \& Technology, 4(2), 104-120.

Morrison, J. (2004). Legislating for good corporate governance. Journal of Corporate Citizenship, $15,121-133$.

Okpara, J. O., \& Wynn, P. (2008). Human resource management practices in a transition economy: challenges and prospects. Management Research News, 31(1), 57-76.

Politis, J. D. (2005). Dispersed leadership predictor of the work environment for creativity and productivity. European Journal of Innovation Management, 8(2), 182-204.

Purcell, J. (2001). The meaning of strategy in human resource management: a critical text. In J. Storey, Human Resource Management (pp. 59-77). London: Thomson Learning. 
Schuler, R. (1992). Strategic human resources management: linking the people wwith the strategic needs of the business. Organizational Dynamics, 21(1), 18-32.

Sen, S., Bhattacharya, C., \& Korschun, D. (2006). The role of corporate social responsibility in strengthening multiple stakeholder relationships. Journal of the Academy of Marketing Science, 158-166.

Shepherd, J. L., \& Mathews, B. P. (2000). Employee commitment: academic vs practitioner perspectives. Employee Relations, 22(6), 555-575.

Smith, A. C., \& Mouly, V. S. (1998). Empowerment in New Zealand firms: insights from two cases. Empowerment in Organizations, 6(3), 69-80.

Taylor, D. W. (2000). Facts, myths, and monsters: understanding the principles of good governance. The International Journal of Public Sector Management, 13(2), 108-124.

Ulrich, D. (1998). A new mandate for human resources. Harvard Business Review, January February, 124-134.

Werner, S. (2002). Recent development in international management research: a review of 20 top management journals. Journal of Management, 28(3), 277-305.

Yun, S., Cox, J., \& Sims, H. P. (2007). Leadership and teamwork: the effects of leadership and job satisfaction on team citizenship. International Journal of Leadership Studies, 2(3), 171-193.

Zhang, D., Zhang, Z., \& Yang, B. (2004). Learnig organization in mainland China: empirical research on its application to Chinese state-owned enterprises. International Journal of Training and Development, 8(4), 258. 